Many were worried that reliable data could not be collected, but Sir Richard Doll decried the fact that six years into the epidemic we know so little about crucial aspects of the spread of AIDS. In particular there is a desperate need for knowledge about the transmission rate of HIV infection by vaginal intercourse, and several speakers pleaded for anonymous testing for HIV antibodies of routine blood samples from pregnant women. Sir Richard and others have recently written to the Lancet calling for reconsideration of parliament's rejection of anonymous testing: they point out that "population based screening is . . . an essential accompaniment of mathematical modelling.",

We do at least have monthly figures of newly diagnosed cases of AIDS, and Professor Michael Healy of the London School of Hygiene and Tropical Medicine has used them to predict the number of new cases in the short term. A model that gave more weight to recent years showed that the present doubling rate of cases of AIDS is about 14 months, but data for 1987 have shown the prediction to be slightly too low. None of the models suggest that the epidemic is abating. The doubling time of the epidemic may be increasing in Europe and the United States, but this is to be expected as those at highest risk tend to become infected early in the epidemic.

Douglas G Altman

Statistician,

Section of Medical Statistics,

Clinical Research Centre,

Harrow HAl 3UJ

1 Black D, Bodmer W, Cox D, et al. HIV testing on all pregnant women. Lancet 1987;ii:1277.

\section{Seasonal affective disorder: the miseries of long dark nights?}

In 1921 Kraepelin described patients who regularly became depressed in the winter months: "Repeatedly I saw in these cases moodiness set in in autumn and pass over in spring 'when the sap shoots in the trees' to excitement, corresponding in a certain sense to the emotional changes which come over even healthy individuals at the changes of the seasons." His words were largely forgotten until this decade, when a group of American psychiatrists became interested in the condition, calling it seasonal affective disorder. ${ }^{2}$

Seasonal affective disorder has now been studied in several centres in the United States and Europe, and the findings are strikingly similar. It is characterised by recurrent depressions that occur regularly in the winter months, remitting in spring and followed in some cases by hypomania. Its incidence is unknown, but it occurs most often in women, with the onset usually in early adulthood. The anxious, irritable mood is accompanied by fatigue, loss of libido, and a profound reduction in socialisation, commonly reflected in work and interpersonal difficulties. ${ }^{3}$ In contrast to non-seasonal depression, the appetite is generally increased, with carbohydrate craving and weight gain, and total time spent in sleep is increased.

After the observation that some patients improved symptomatically on travelling south in the winter, artificial light was tried therapeutically. It is now agreed that up to $85 \%$ of patients will respond to bright light given for between two and six hours a day. ${ }^{46}$ The intensity used is less than that of a normal sunny day and may be easily given using a fluorescent lamp box. Patients show improvement on standard mood scales within two to four days of starting treatment and relapse within three days of withdrawal. ${ }^{6}$ Adverse effects of phototherapy have not been described, and there is no evidence that light induces mania in patients with seasonal affective disorder.

Similarities have been drawn between seasonal affective disorder and hibernation. Thus studies have been done in animals to try to explain both the aetiology of seasonal affective disorder and the mechanism of action of light treatment. In many animals seasonal rhythms are synchronised by environmental time cues. Of these, the photoperiod-that is, the length of daylight hours - is the most important. Experimental alteration of the photoperiod affects seasonal behaviour. ${ }^{8}$ For example, in hamsters the infertility and weight gain of hibernation can be prevented in winter by laboratory exposure to long summer type photoperiods. Information about the environmental photoperiod is relayed from the retina through the hypothalmic suprachiasmatic nucleus to the pineal gland, where it influences secretion of melatonin. ${ }^{9}$ Melatonin is released nocturnally and suppressed by light ${ }^{10}$ and is thought in animals to be crucially important in mediating the effect of light on seasonal behaviour. ${ }^{11}$

If the photoperiodic model is applicable to seasonal affective disorder and symptoms are caused by a short day length light therapy should act by prolonging the daylight hours. If this were the case only light given at either end of the day would be effective. The timing of light therapy is not critical, however, and it is equally useful when given in the middle of the day. ${ }^{12}$ As light is known to suppress melatonin it was suggested that it might be working in seasonal affective disorder by correcting an abnormal activity or secretory rhythm of the hormone. It was reported that the onset of nocturnal release of melatonin in seasonal affective disorder may be delayed by two hours and that light resynchronises the rhythm. ${ }^{4}$ Current work disputes this, however, and shows that the secretion of melatonin is normal in seasonal affective disorder ${ }^{13}$ and that the antidepressant efficacy of light is independent of its effect on melatonin. ${ }^{1314}$

Thus the initial expectation that winter depression might be a photoperiodic phenomenon has not been confirmed, and the method by which light treatment works is still not clear. The extent to which light exerts a placebo effect has still to be resolved. In other groups of patients depression recurs exclusively in spring, summer, or autumn. Such annual rhythms in mood may have either a biological or a psychosocial basis.

Melanie Abas

Clinical research worker

DeCLAN MURPHY

Clinical research worker

Institute of Psychiatry,

London SE5 8AF

1 Kraepelin E. (Barclay RM, transl.) In: Robertson GM, Livingstone E, Livingstone S, eds. Manicdepressive illness and paranoia. Edinburgh: $\mathrm{E}$ and $\mathrm{S}$ Livingstone, 1921.

Rosenthal NE, Sack DA, Gillin JC, et al. Seasonal affective disorder: a description of the syndrome and preliminary findings with light therapy. Arch Gen Psychiatry 1984;41:72-80.

syndrome and preliminary findings with light therapy. Arch Gen Psychiatry 1984;41:72-80. to mode of referral and diagnostic subtype. $\mathcal{I}$ Affect $D$ is (in press).

4 Lewy AJ, Sack RL, Miller LS, Hoban TM. Antidepressant and circadian phase-shifting effects of light. Science 1987;235:352-4.

5 Wirz-Justice A, Bucheli C, Graw P, Kielholz P, Fisch H, Woggan B. Light treatment of seasonal affective disorder. Acta Psychiar Scand 1986;74:193-204.

6 James SP, Wehr TA, Sack DA, Parry BL, Rosenthal NE. Treatment of seasonal affective disorder with evening light. Br f Psychiatry 1985;147:424-8. 
7 Immelman K. Role of the environment in reproduction as source of "predictive" information. In: Farner DS, ed. Breeding biology of birds. Washington DC: National Academy of Sciences, 1973:121-47.

8 Hoffman K. Photoperiodism in vertebrates. In: Aschoff J, ed. Handbook of behavioural neurobiology. New York: Plenum Press, 1981:449-73.

9 Moore RY. The innervation of the mammalian pineal gland. In: Reiter RJ, ed. The pineal gland and reproduction. Basel: Karger, 1978:1-29.

10 Lewy AJ, Wehr TA, Goodwin FK, Newsome DA, Markey SP. Light suppresses melatonin secretion in humans. Science 1980;210:1267-9.

11 Hastings MH, Herbert J, Martensz ND, Roberts AC. Melatonin and the brain in photoperiodic mammals. In: Evered D, Clark D, eds. Photoperiodism, melatonin and the pineal. London: Pitman, 1985:57-77.

12 Wehr TA, Jacobson FM, Sack DA, Arendt J, Tamarkin L, Rosenthal NE. Phototherapy of seasonal affective disorder. Arch Gen Psyckiatry 1986;43:870-5.

13 Murphy D, Abas M, Checkley SA. Sensitivity to light in seasonal affective disorder. In: Thompson C, Silverstone T, eds. Seasonal affective disorder. London: CNS Neurosciences (in press).

14 Winton F, Corn T, Huson LW, Franey C, Arendt J, Checkley SA. Effects of light treatment upon mood and melatonin in patients with seasonal affective disorder. In: Thompson C, Silverstone T, eds. Seasonal affective disorder. London: CNS Neurosciences (in press).

\title{
Crisis in the National Health Service
}

On 7 December the presidents of the Royal Colleges of Physicians, Surgeons, and Obstetricians and Gynaecologists issued the following joint statement

Each day we learn of new problems in the NHS-beds are shut, operating rooms are not available, emergency wards are closed, essential services are shut down in order to make financial savings. In spite of the efforts of doctors, nurses, and other hospital staff patient care is deteriorating. Acute hospital services have almost reached breaking point. Morale is depressingly low.

It is not only patient care that is suffering. Financial stringencies have hit academic aspects of medicine in par- ticular, because of the additional burden of reduced University Grants Committee funding. Yet the future of medicine depends on the quality of our clinical teachers and research workers.

Face saving initiatives such as the allocation of $£ 30 \mathrm{~m}$ for waiting lists are not the answer. An immediate overall review of acute hospital services is mandatory. Additional and alternative funding must be found. We call on the government to do something now to save our health service, once the envy of the world.

SIR RAYMOND HOFFENBERG IAN P TODD SiR GEORge PINKER

\section{Regular Review}

\section{Community care I: problems}

\author{
ELAINE MURPHY
}

In December 1986 the Secretary of State for Social Services announced that Sir Roy Griffiths would undertake a review of community care. His report is expected early in the New Year. The announcement that Griffiths was to conduct a review caused both hopeful excitement and sceptical anxiety among professionals struggling to develop community based services for people with chronic health problems. The "nonacute" sector of the health service hopes that he will recommend innovations that will have as much impact on community services as the first Griffiths report had on National Health Service management. ${ }^{1}$ His terms of reference are "to review the way in which public funds are used to support community care policy and to advise on the options that would improve the use of these funds as a contribution to more effective community care." Sir Roy has advisers with an interest in community care and is supported by a small departmental team of administrators.

The King's Fund has meanwhile produced its own evidence and recommendations to Griffiths in the form of two memoranda, Facilitating Innovation in Community Care and Making a Reality of Community Care, which draw together the fund's wide knowledge and experience. ${ }^{23}$ Three other reports will be influential in shaping the final report: firstly, the well publicised report from the Audit Commission, Making a Reality of Community Care,${ }^{4}$ which suggests major reforms in the statutory services; secondly, the report of the Joint Working Party on Public Finance and Residential Care, Public Finance and Residential Care (the Firth report), ${ }^{5}$ which has recommended a substantial change in the way supplementary benefit is used to support 